probable on the whole that the ultimate explanation of this, as of all after-images of motion, will be somehow formulated in terms of impulses to movement aroused by the particular stimulation that precedes. Perhaps the experiments here recorded may contribute their mite towards this final explanation, if that ever comes.

Amherst College.
A. H. Pierce.

\section{RAFINESQUE'S WESTERN MINERVA, OR AMERICAN ANNALS OF KNOWLEDGE AND LITERATURE.}

Ir has been the writer's good fortune to discover in the library of the Academy of Natural Sciences of Philadelphia a copy of Rafinesque's Western Minerva, or American Annals of Knowledge and Literature, of which the only information possessed had been taken from the prospectus published as an advertisement in the Kentucky Reporter of 1820. The great rarity of the work is explained by its author in his 'A Life of Travel' (1836), page 66, as follows: "Ever since 1821 I had proposed to publish - a literary and learned journal, the Western Minerva; subscribers were procured, the printer had also made a contract with me, and the first number was printed; when he dared to suppress it, at the request of some secret foes of mine, who probably paid him for it. I only savèd three copies of it ***."

The copy now under observation is a small quarto, with a page measurement of $113 \times 183$ millimeters (exclusive of margins). The matter is printed in two columns to the page, and consists of vi +82 pages, of which the preface and dedication are not double-columned, and pages 81-88 are without doubt original proof sheets, as they are printed on one side only, and bear corrections in ink of typographical and other errors, with such notes as "I must see another proof," etc.
Aside from the rarity of the work, it contains several articles of extreme interest to naturalists, as new names for plants are proposed which have not as yet been noted in synonymy, or else have not been given such an early date in scientific nomenclature. In bringing these matters to the attention of those interested it has seemed advisable to describe the work from the beginning, referring to the non-scientific articles, or the apparently least interesting of these, by title only.

Western Minerva, | or | American Annals | of Knowledge and Literature, | Un peu de tout, | Food for the Mind, | first volume, | for 1821, | Lexington, Kentucky. | Published for the editors, by Thomas Smith, in quarterly num- / bers, four of which form a volume, at $\$ 2$ per annum. | 1821.

Page ii. Blank.

Page iii. Dedication, "To the Trustees, President, Professors and Tutors of Transylvania University $* * *$."

Page iv. Blank.

Pages v, vi. Preface [Dated Lexington, January, 1821].

Page 7. Headed with the title as on title-page to the word literature, with the addition of the following: Containing original essays upon Science, the Arts, Literature, and subjects connected with the Civil and Natural history of the Western States. Vol. I. Lexington (Ky.), January, 1820. No. 1.

Pages 7-11. Under the heading Legislation, is Principles of Political Wisdom, *** Translated from the Greek by Benjamin Franklin.

Pages 11-18. Ethics, or Moral Philosophy. The Moral Decameron $* * *$ Translated from the Greek $* * *$ by Benjamin Franklin.

Pages 18-22. Metaphysics. Theory of the Creation or Emanation of Beings, etc. [Signed, Leibnitz and dated Lexington, October, 1820$]$. 
Pages 22-26. Astronomy. Enquiries on the Sidereal, or Upper Spheres, by Professor C. S. Rafinesque. [Among other things the author recognizes three kinds of comets, and brings forward the names Dromets and Tychomets. For 'revolving stars' he proposes Geophosies. Dated, Transylvania University, 22d October, 1820].

Pages 27-29. Meteorology. Letter on Atmospheric Dust, addressed to Governor De Witt Clinton, Albany. [Signed by C. S. Rafinesque, Transylvania University, 1st, October, 1820].

Pages 29-31. Physics. On a New Property in Light, by Captain Forman. With Notes, by C. S. Rafinesque [pp. 29, 30]. Synopsis of some Discoveries on Heat, made in 1818 [pp. 30, 31. Signed M.].

Pages 31-33. Mathematics. On Descriptive Geometry [p. 31. Signed M.]. On Isomerical Numbers, or Common Multiples [pp. 31-33. Signed Archimedes].

Pages 34-37. Chemistry. Synopsis of the Principal Discoveries, etc., made in 1818 [p. 34. Signed M.]. Chemical Art of Converting pure Woody Substances into Gum and Sugar, etc. (Abridged by Professor Rafinesque) [pp. 35-37]. Selection of late European Discoveries in Chemistry [p. 37. Signed M.].

Pages 37-38. Mineralogy. New Mineral Species discovered or ascertained in 1818 [pp. 37, 38. Signed M.]. Notice on the Hydraulic Limestone, by H. De Witt Clinton, Governor of the State of New York, etc., in a letter to Professor Rafinesque. [p. 38. Letter signed by D. C., and dated Albany, September, 1820. The chemical analysis of the limestone is given by Clinton as follows: 35 parts carbonic acid, 25 lime, 15 silex, 16 alumine, 2 water, 1 oxide iron, 6 loess $=100$. An appended note by Rafinesque further describes the material.]

Pages $38-40$. Original Scientific Intelligence, or Discoveries and Remarks on Natural Sciences; extracted from a letter of
Dr. John Torrey, $* * *$ to Professor Rafinesque. [One of the large tuckahoes from the southern States is given the name of Sclerotium giganteum, being the largest species known; the substance of the fungus is a new principle for which the name 'Sclerotin' is proposed. The discovery of Datholyte at Paterson, N. J., is recorded, and a new mineral from Schooley's Mountain, N. J., is described and named Siderographite. Oryzopsis melanocarpa Muhlenb. and $O$. asperifolia Mich. are differentiated; the latter is not an Oryzopsis, and Muhlenberg's species is referred as a synonym to Milium racemosum Smith. The letter is signed J. T., and dated N. York, 28th July, 1820.]

Pages 40-43. Botany. Botanical Discoveries made in Kentucky in 1820, by Professor Rafinesque, extracted and translated from a letter to Professor Decandolle of Geneva, *** [pp. 40-42. Dated Lexington, 1st December, 1820. The genera Enemion and Stylypus are characterized, the latter evidently the same as Stylipus Raf. (1825), the type being $S$. vernus, in both instances. A new genus allied to Sedum, but differing in ' having 4 unequal petals and 4 monosper. mous capsules,' is named Aectyson, with $A$. sagittatum, which has 'cylindrical scattered leaves, sagittate at the base, the flowers in a polystachyous umbel, the petals white lanceolate carinate acute,etc., as the type.' The author suggests that this plant is close to Sedum pulchellum and the latter may be congeneric. The relationship of Jeffersonia binata to the 'family of Berberides' is noted; that Rhamnus lanceolatus Pursh, belongs to the genus Frangula; that two species of Buck-eye trees are blended under the name of Pavia pallida, which he calls $P$. ochroleuca and $P$. axillata, but gives no descriptions. The genus Cubelium is named for Viola concolor, which makes the date of establishment of the genus 1821, instead of 1824, as has been quoted. He has ascertained more than 
twenty new species of plants, among which he mentions Ranunculus mutabilis, Trillium revolutum, Monarda pratensis, Eupatorium serotinum, Silene fistulosa, Cactus mesocantha, Hepatica parviflora, etc., none of which he describes. The name Eupatorium serotinum was used by Michaux in 1803 . Other proposed names which have not found their way into synonymy are Gentiana glauca, Pediculars [sic] villosa, Martynia rotundifolia, Veronica connata, Zigadenus angulosus. It is pointed out that Gentiana amarelloides Michaux is not the same as $G$. quinqueflora Linné, with which Pursh had confused it. Among some plants received ' from some ladies,' three new ones are mentioned: Lysimachia (Trydinia) glauca, Gentiana azurea, and Trillium reflexum, the latter 'differing from $T$. sessile, by its petiolated leaves, reflexed calyx and pale purple petals.' Some new names for plants from Missouri are Gnaphalium nemocladum, Melothria alba, Asplenium glaucum, A. falcatum, but which are also not described. Melothria nigra Raf. 'is common near Natchez.' And the following are recorded from Kentucky presumably for the first time: Pancratium liriosme Raf., Iris brevicaulus Raf., Ptelea trifoliata, Arenaria divaricata, Lobadium trifoliatum Raf. (Rhus aromaticum Ait.), Triosteum minor, Nelumbium pentapetalum, Agave virginica, Iris cristata, etc. In a postscript Rafinesque states that a new genus, Geminaria, must be formed for Phyllanthus Carolinianus Walter and Michaux (called $P$. obovatus by Wildenow, Persoon, Pursh, and Nuttall). Signed C. S. R.].

On the several species of the genus Clintonia, addressed to Dr. Samuel L: Mitchell, in a letter dated September 26, 1819 [pp. 42, 43. This is a review of the genus. The author reverses his former opinion that Dracena borealis Aiton, and Convallaria umbellulata Michaux are synonymous. Four species are recognized as fol lows: "1. Sp. Clintonia nutans. Leaves with ciliate margin, keel smooth: umbel sub-corymbose, pedicels smooth naked nodding unequal, perigone campanulate, sepals oblong sessile subacute.-Dracena borealis Ait. Wild. Pers. etc., flowers lerge [sic] yellowish inodorous. New York to Canada on mountains. Var. 1. Prolifera. Corymb proliferous.-Var. 2. Fascicularis, flowers in separate fascicles. 3. Obovata. Leaves nearly obovate. 4. Dasistema, scape pubescent. 5. Macrostema. Scape longer than the leaves. Var. 6. Uniflora, etc."

"2. Sp. Clintonia podanisia. Leaves with ciliate margin, keel smooth ; scape pubescent longer than the leaves; umbel erect, pedicels unequal pubescent naked, the longest erect, the others incurved : perigone semi-campanulate, sepals oblong, sessile, acute.-Discovered in July, 1819, on the Laurel ridge in Pennsylvania. Flowers pretty large whitish, inodorous. Var. 1. Biflora, with only 2 flowers, the shortest with incurved pedicel, leaves narrow, semicuneate. Var. 2. Glabrata. Scape smooth. Var. 3. Fascicularis. 2 umbels, the second lateral, each with 3 or 4 flowers. Var. 4. Phyllostema. One small lanceolate and acute leaf on the scape."

"3. S. Clintonia parviflora. Leaves with pilose margin and keel, scape pubescent, equal to the leaves; umbel creet [sic]* 5-8 flore, pedicels equal, naked pubescent erect, perigone semi-rotate, sepals semi-onguiculated [sic], claws erect, disk oboval obtuse. Discovered in July, 1819, on the top of the Allegheny Mountains in Maryland. Flowers small, perfectly white, nearly inodorous. Var. 1. Plicata. Leaves folded falcated. Var. 2. Abortiva. Some abortive sessile flowers in the umbel."

"4. Sp. Cintonia [sic] odorata. Leaves oblong-oval, with ciliate margin and keel ; scape pubescent, umbel erect, pedicels bracteated.-Convallaria umbellulata Mx. Pers., * Erect? 
etc. This character is from the imperfect account of Michaux, who did not mention the shape of the perigone nor sepals; but the bracteated white fragrant flowers appear to entitle it to be deemed a peculiar species. Native of the Alleghany Mountains. Var. 1. Punctata. Flowers with red dots inside." Signed C. S. Rafinesque, and dated Lexington, 10th September, 1819.]

Pages 43-46. Agriculture. Practical Remarks and Results on the Agriculture of the Western States, or on the Cultivation of Corn, Wheat, Hemp and Tobacco in 1820. [Signed Agricola; dated Fayette county, Ky., 16th November, 1820.]

Pages 47, 48. Manufactures. On the various Manufactures from Flour. [Signed Agricola.]

Pages 49-52. Statistics. Statistical View of the Town of Lexington in Kentucky, in December, 1820 [p.49. Signed M.]. View of the Public Institutions for Instruction in Spain and the United States [p. 50. Anonymous]. United States of America [p. 51. Signed Mentor]. Remarks on Public Instruction in the State of New York [pp. 51, 52. Signed Mentor].

Pages 53-57. Archæology. Alleghawee Antiquities of Fayette County, Ky., in a letterof Professor Rafinesque to the American Antiquarian Society. [Signed C. S. R. and dated Lexington, 3d January, 1821.]

Pages 57-59. Medicine. On some specific remedies for Mortification, Consumption, Hydrophobia, etc. [pp. 57, 58. Signed D. R.] Notices of Materia Medica, or new medical properties of some American Plants [pp. 58, 59. Medicinal properties are ascribed to Erythronium albidum, Helonias angustifolia, Helenium autumnale, Evonymus atropurpureus, Euphorbia peploides, Triosteum major, Tr. minor, Sabatia angularis, Gentiana amarelloides. Rafinesque states that he has found the Bear-grass, Helonias angustifolia Michaux to be different from
Helonias and calls it Cyanoteris pratensis. Signed C. S. R.].

Pages 59-60. Discoveries. Selection of late American Discoveries. [Signed W. M.]

Pages 60-80. Literature and Varieties The Sifter.-No. 1. [pp. 60-62. Signed Z.] . The Querist.-No. 1. [pp. 62-64. Signed W. M.]. Female Free-Masonry.-No. 1. [pp. 64, 65. Signed O. I.]. Western Literature. Works published in the Western States in 1820 [pp. 66, 67. Signed W. M.]. The Sphynx.-No. 1. [p. 67. Signed Oedipus]. Polygryphs [p. 67. Signed Constantine]. The Monkeys.-No. 1. [pp. 68, 69. Signed P. Hystrix, M.D.]. Future Epitaphs. By Doctor Porcupine Hystrix, of Cincinnati [pp. 69, 70]. Fragments of Correspondence, containing Fragments of a letter of Mr. Bory St. Vincent $* * *$ to Professor Rafinesque, [dated Bruxelles, 10 August, 1820], 'Annals of Physical Sciences' [p. 71]. Zoological Illustrations, by W. Swainson [pp. 71, 72]. Fragments of a letter to Mr. Bory St. Vincent at Paris $* * *$ on various subjects $* * *$ [Dated Lexington, 7th January, 1821. Rafinesque takes occasion to refer to his antagonists as a "set of unfortunate individuals, who have two eyes; but cannot see; their minds are deprived of the sense of perception; they are astonished and amazed at my discoveries, and are inclined to put them in doubt and even to scoff at them $* * *$ our catfish, eels, shads [sic], sturgeons, etc., are for them mere fish to fill their stomach! and moreover they are all of European breed, and were carried here by Noah's flood direct from the Thames, the Seine and the Rhine! -I let them rail to their hearts' content, and I laugh at them $* * *$ " and further he continues, "It is only in Europe that my labors and discoveries may be appreciated: here I am like Bacon and Galileo, somewhat ahead of the age and my neighbors; ***" and further, "The Western Minerva has been threatened before her 
birth" Signed C.S.Rafinesque]. Fragments of letters from Lexington. By a Lady [pp. 77-79. Deals with social life in Lexington. Signed Lavinia]. A view of some American Universities and Colleges in 1820 [pp. 79, 80. Signed W. M.]. 6. Transylvania University [p. 80. Signed W. M.].

Pages 81-88. Poetry. The Western Muse, or, Original Poetry. Les Rives de l' Ohio. Poeme en deux chants [pp. 81-82. Signed C. S. R.]. Couplet pour Silvie [p. 83. Signed C. S. R.]. A Melody, My Heart is Gone [p. 83. Signed M. T.]. A Melody. The Man I'll Love [p. 83. Signed Virginia]. La Double Aurore. Ode Anacreontique [pp. 83, 84. Signed C. S. R.]. Le Reveil d' Irma. Ode Anacreontique [p. 84. Sign'ed C. S. R. and dated October, 1819]. L' Enfant et l' Epouse Endormis. Romance [p. 84. Signed C. S. R. and dated October, 1819.] Preceptes Moraux. 1. Le Secret d' etre hereux. 2. Amour et Jealousie [p. 84. Signed C. S. R.]. The Blind Lover [p. 85. Signed Milton]. Lines to Maria. Who asked me if I should like to Love in a Cottage [p. 85. Signed Constantine]. To Silvia [pp. 85,86. Signed J. R.]. Trifles. By Billy Tickler of Frankford [p. 86 . Signed B. T.]. Italian Stanzas. Un Consiglio d'Amore [p. 86. Signed Constantine]. Epigrams [p. 87]. The Elysian Dream. To my Sister [p. 87. Signed Eleonora]. To the Sun. To the Moon. On the Loss of a Friend [p. 88. All three signed Eleanora]. One Word and Only One. To Eliza. To Miss $\mathrm{M}-$, who wished to know what she should read [p. 88. Both signed Oscar].

The copy of the work before me bears the autograph of S. S. Haldeman, one of the early members of the Academy of Natural Sciences of Philadelphia. It is known that Rafinesque advertised a copy for sale at $\$ 5.00$, stating it to be unique, and it is not unlikely that the present one is that copy, which has been in the Academy's library for many years, although nothing is known of its history.

WM. J. Fox.

Academy of Natural Sciences of Philadelphia.

THE INTERNATIONAL CATALOGUE OF SCIENTIFIC LITERATURE.*

I. -OBJECT AND NATURE OF THE CATALOGUE.

THE object and nature of the Catalogue were defined by means of the following resolutions of the 1896 Conference, which were agreed to nemine contradicente. The resolutions are re-numbered, but the original numbers are given in brackets :-

1. [12] That it is desirable to compile and publish by means of some international organization a complete Catalogue of Scientific Literature, arranged according both to subject-matter and to authors' names.

2. [13] That in preparing such a Catalogue regard shall, in the first instance, be had to the requirements of scientific investigators, to the end that these may, by means of the Catalogue, find out most easily what has been published concerning any particular subject of inquiry.

3. [17] That in indexing according to subject-matter regard shall be had, not only to the title (of a paper or book), but also to the nature of the contents.

4. [18] That the Catalogue shall comprise all published original contributions to the branches of science hereinafter mentioned, whether appearing in periodicals or in the publications of Societies, or as independent pamphlets, memoirs or books.

5. [25] That a contribution to science for the purposes of the Catalogue be considered to mean a contribution to the mathematical, physical, or natural sciences, such as, for example, mathematics, astronomy, physics, chemistry, mineralogy, geology, botany, mathematical and physical geogra-

* Scheme of publication approved by the International Conference of 1900 . 